
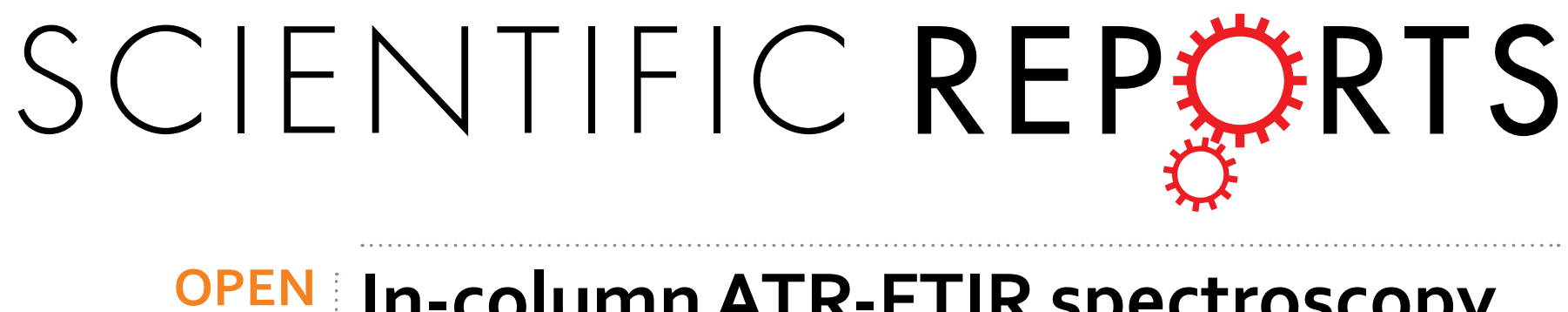

\title{
In-column ATR-FTIR spectroscopy to monitor affinity chromatography purification of monoclonal \\ antibodies
}

Received: 31 May 2016

Accepted: 04 July 2016

Published: 29 July 2016

\author{
Maxime Boulet-Audet ${ }^{1,2}$, Sergei G. Kazarian ${ }^{1}$ \& Bernadette Byrne ${ }^{2}$
}

In recent years many monoclonal antibodies (mAb) have entered the biotherapeutics market, offering new treatments for chronic and life-threatening diseases. Protein A resin captures monoclonal antibody (mAb) effectively, but the binding capacity decays over repeated purification cycles. On an industrial scale, replacing fouled Protein A affinity chromatography resin accounts for a large proportion of the raw material cost. Cleaning-in-place (CIP) procedures were developed to extend Protein A resin lifespan, but chromatograms cannot reliably quantify any remaining contaminants over repeated cycles. To study resin fouling in situ, we coupled affinity chromatography and Fourier transform infrared (FTIR) spectroscopy for the first time, by embedding an attenuated total reflection (ATR) sensor inside a microscale column while measuring the UV $280 \mathrm{~nm}$ and conductivity. Our approach quantified the in-column protein concentration in the resin bed and determined protein conformation. Our results show that Protein A ligand leached during CIP. We also found that host cell proteins bound to the Protein A resin even more strongly than $\mathrm{mAbs}$ and that typical CIP conditions do not remove all fouling contaminants. The insights derived from in-column ATR-FTIR spectroscopic monitoring could contribute to mAb purification quality assurance as well as guide the development of more effective CIP conditions to optimise resin lifespan.

Monoclonal antibodies (mAbs) have emerged as one of the most important classes of biotherapeutics. The high specificity of mAbs means that they bind to target molecules very effectively, reducing the risk of therapeutic side effects ${ }^{1}$. However, the cost of production of biotherapeutic antibodies is considerably higher than that of small molecule drug manufacture due largely to stringent purity requirements imposed by regulatory bodies ${ }^{2}$. For instance, the World Health Organisation, recommends host cell protein (HCP) and DNA limits of $100 \mathrm{ppm}$ and $10 \mathrm{pg}$ per dose respectively ${ }^{3-6}$. To ensure that the appropriate purity has been achieved following purification, qPCR can quantify trace amounts of host cell $\mathrm{DNA}^{7}$, while enzyme-linked immunosorbent assay (ELISA) are usually used to measure levels of HCP and protein A ligand leaching as a result of enzymatic cleavage ${ }^{8,9}$.

To achieve high protein purity, the culture fluid first undergoes depth filtration before successive preparative chromatography steps ${ }^{10,11}$. The first step affinity chromatography can clear over $98 \%$ of HCP and inactive protein fragments in a single step with a ligand designed to bind only the appropriately folded full-length $\mathrm{mAb}$ product $\mathrm{t}^{2,12,13}$, prior to anion and cation exchange chromatography steps which remove most remaining impurities ${ }^{10,14-16}$.

For mAb capture, Protein A cross-linked to agarose is most commonly used as the matrix ${ }^{17-20}$, but harder silica matrices have also been developed ${ }^{21}$. The affinity chromatography step is usually regarded as the bottleneck of the $\mathrm{mAb}$ purification process due to relatively low throughput. Ingenious semi-continuous processes have been developed to overcome this limitation ${ }^{22}$, but most industrial processes operate in batch mode. With a price of around $2000 \$ / \mathrm{kg}^{2,23}$, Protein A affinity resin costs over 30 times more than other types of resin ${ }^{24}$. Unfortunately, cheaper alternatives using de novo synthetic ligands do not offer the same specificity and level of HCP clearance ${ }^{10,12,25}$.

${ }^{1}$ Department of Chemical Engineering, Imperial College London, South Kensington Campus, London, SW7 2AZ, UK. '2Department of Life Sciences, Imperial College London, South Kensington Campus, London, SW7 2AZ, UK. Correspondence and requests for materials should be addressed to S.G.K. (email: s.kazarian@imperial.ac.uk) or B.B. (email: b.byrne@imperial.ac.uk) 
However, the binding capacity of affinity resin decays over repeated purification cycles $^{6,20,26,27}$. Depending on the required purity of the sample, the resin needs to be replaced after 80 to $200 \mathrm{cycles}^{20,26}$. Binding capacity decay makes affinity resin the most expensive consumable for $\mathrm{mAb}$ production, representing over $50 \%$ of the raw material cost ${ }^{2}$. Thus, pharmaceutical companies have a strong incentive to extend resin lifetime through improvement of purification strategies ${ }^{22,28}$.

The causes of binding capacity decay remain elusive despite several previous studies. Fouling by irreversible protein binding may be responsible for limiting access to the protein ligand, reducing binding capacity. Culture fluid containing $\mathrm{mAb}$ product appears to cause more fouling than null-cell culture fluid ${ }^{29}$. Protein fouling can occur during $\mathrm{mAb}$ capture or following low $\mathrm{pH}$ elution. The low $\mathrm{pH}$ employed during elution promotes aggregation of $\mathrm{mAbs}^{30}$ which could then become trapped in the resin pores ${ }^{10,14,26,29}$. Moreover, hydrophobic HCPs such as histone $e^{8}$ and antibody fragments can bind to the mAb product during capture to form mixed protein aggregates ${ }^{29}$. Such aggregates are detectable using a range of techniques such as CD, DSC, micro-rheology, Raman, analytical ultra-centrifugation, and light scattering 4 .

To clear non-eluting proteins from the resin, a wide range of cleaning-in-place (CIP) protocols were developed $^{18,28,31}$. CIP typically involves flowing diluted sodium hydroxide through the column between purification cycles to hydrolyse deposits while sanitizing the resin ${ }^{28,31,32}$. A reducing solution followed by a chaotropic solution also proved an effective CIP strategy ${ }^{28,33}$. This alkaline treatment extends resin lifespan, but it also appears to decrease the binding capacity ${ }^{26}$ due to either Protein A leaching ${ }^{4,34,35}$ or ligand denaturation ${ }^{36}$. Under alkaline conditions, asparagine and glutamine residues in Protein A are susceptible to deamidation which also decreases binding capacity ${ }^{37,38}$. Substitution of these residues resulted in a mutant Protein A with enhanced alkaline resistance ${ }^{17}$. Branded MabSelect SuRe, this more resistant affinity resin rapidly became the market leader ${ }^{20}$.

However, our previous work suggested that sodium hydroxide affects the protein conformation of the ligand, even in the MabSelect SuRe resin ${ }^{36}$. Resin lifespan depends highly on operating conditions, sample preparation, and sample origin ${ }^{39}$. These variables usually leave room for further CIP protocol optimization ${ }^{26,28}$

Based on post-column UV absorption, high throughput static binding capacity assays measure unbound $m A b s$ after elution, enabling the study of many different experimental conditions ${ }^{28,36}$. Dynamic binding capacity (DBC), more representative of the purification process, is also widely employed to assess resin lifespan ${ }^{19,26,27}$. DBC describes the amount of sample that will bind to a resin packed in a column under defined conditions. Calculating the height equivalent to theoretical plate (HETP) quantifies the column's separation potential ${ }^{26,41}$. The shape of the elution peak indicates the lifespan decay ${ }^{4}$. Multivariate analysis of several chromatographic variables can enhance the precision of lifespan estimation ${ }^{40}$.

The analysis of cleaning eluents by surface-enhanced laser desorption/ionization time-of-flight mass spectrometry (SELDI-TOF-MS) and 2D-PAGE can provide details of the chemical profile of the fouling contaminants ${ }^{28,41,42}$. Unfortunately, mobile phase analysis does not reveal bound fouling contaminants while preserving the resin intact. Transmission and scanning electron microscopy of fouled resin beads clearly showed irreversible containment accumulation ${ }^{6,14,31,43}$. Although these studies were very informative, they were performed on dried resin beads, bearing little resemblance to the hydrated gel ${ }^{44}$. Direct measurement of hydrated resin is required to gain more detailed insights into fouling.

Direct in-column analyses are more representative of the chromatographic media. Confocal Laser Scanning Microscopy (CLSM) enabled direct visualization of protein binding in situ ${ }^{6,14,29,45}$. Such an approach combined with labelled proteins offers enhanced sensitivity for fluorescent light imaging ${ }^{46}$. Magnetic resonance imaging ${ }^{47}$ and X-ray computed tomography ${ }^{48}$ both offer in-column non-invasive probing of packed beads but the signal measured lacks specificity to potential fouling constituents and resin.

To investigate resin fouling in situ, we chose Fourier transform infrared (FTIR) spectroscopy as a detection method. FTIR spectroscopy is a non-destructive and label-free method capable of measuring gases, liquids or solids. In addition, FTIR spectroscopy allows quantification of solute ${ }^{49,50}$. The fast response of infrared detectors can monitor rapid dynamic processes such as samples flowing from a chromatographic column ${ }^{43,51}$. Organic molecules absorb mid-infrared light of specific frequencies, resulting in highly individual infrared spectra giving each species a distinct chemical footprint.

The fact that positions of the amide bands in infrared spectra are dependent on the protein secondary structure is particularly relevant for protein characterisation ${ }^{49,52-60}$. For instance, this detection method has been successfully applied to protein aggregate analysis ${ }^{49,61,62}$. FTIR spectroscopy thus enables the quantification of both antibody load and HCP impurity concentration in cell culture fluid with a detection limit around $0.7 \mathrm{mg} / \mathrm{mL}^{60,63}$ and can discriminate between the different constituents of the affinity chromatographic bed ${ }^{36}$. Agarose beads were previously studied in situ by infrared spectroscopy in transmission mode. Since water absorbs strongly in the mid-IR range, the transmission cell path length cannot be thicker than several micrometers, limiting the analysis to a single layer of squashed beads of small diameter ${ }^{64}$.

Attenuated total reflection (ATR) overcomes the optical path length limitation by probing only a layer of a few micrometers adjacent to the surface of the ATR crystal ${ }^{36,49,56,64}$, to study protein adsorption ${ }^{36,49,57-59,65}$. As contaminants concentrate mainly on the outer layer of beads ${ }^{29}$, ATR should be particularly sensitive to irreversibly adsorbed protein. Previously, in-column ATR-FTIR spectroscopic detection was only reported for chiral liquid chromatography on mesoporous silica beads smaller than $20 \mu \mathrm{m}^{43}$. However, recent work from our group demonstrates ATR-FTIR spectroscopy to be an effective means of measuring unaltered hydrated affinity resin beads of diameter ranging from 50 to $150 \mu \mathrm{m}$ by applying a small controlled load on the resin bed ${ }^{36}$. Building on our earlier studies, here we embedded an ATR-FTIR spectroscopic detector within an affinity liquid chromatography column for the first time and exploited the advantages of in-column ATR-FTIR spectroscopy to study the fouling of Protein A affinity resin in situ. Our microchip-based approach measured the purification process of a common $\mathrm{mAb}$ using the MabSelect SuRe standard resin widely used in industry ${ }^{20}$. The in-column detection revealed the 

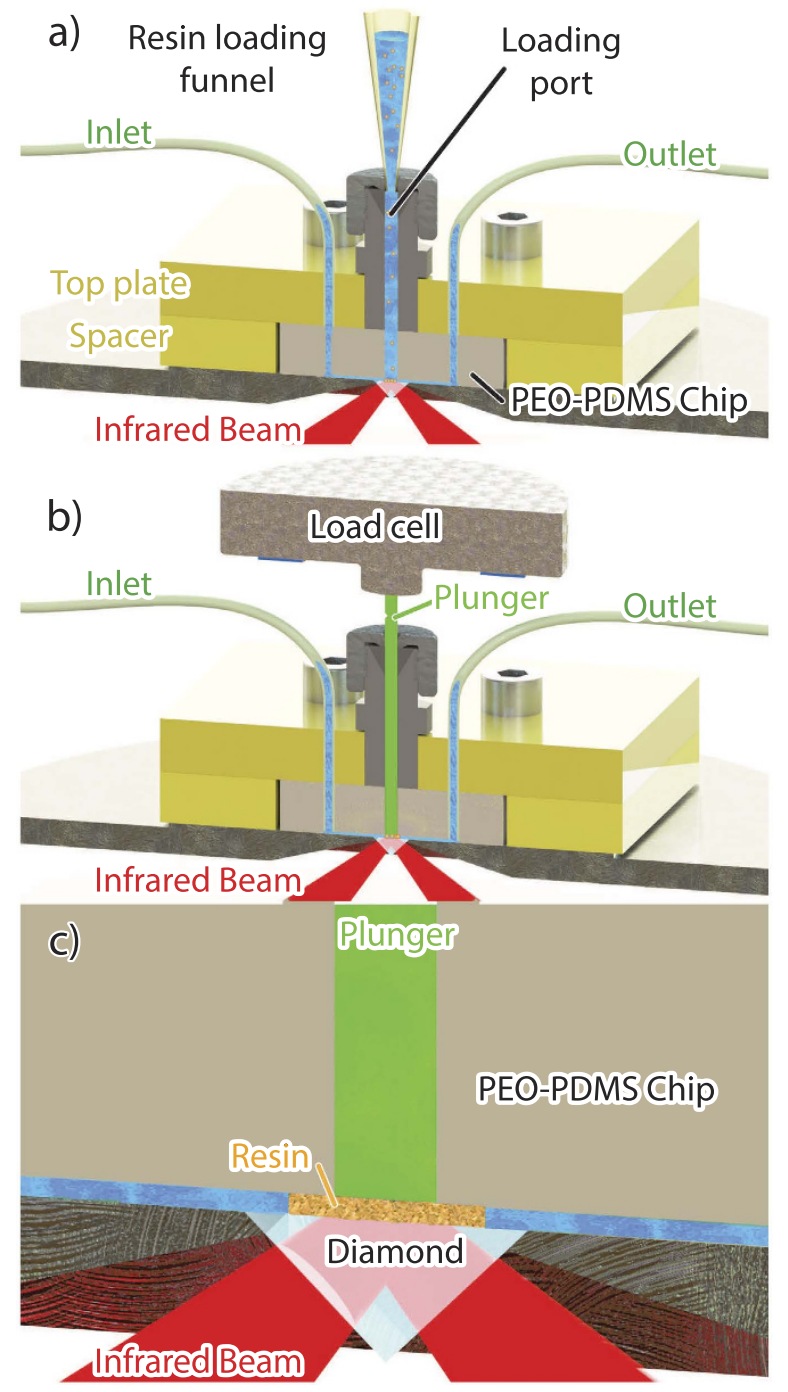

Figure 1. (a) Schematic of the experimental set-up for in-column ATR-FTIR spectroscopy with fitted funnel for resin loading. The poly-dimethylsiloxane (PDMS) cell was clamped to the ATR accessory using an acrylic top plate (yellow) connected to both the inlet and outlet. (b) Schematic of the experimental setup with the polyether ether ketone (PEEK) plunger (green) securing the resin bed while buffer flows from the inlet to the outlet. The force applied was measured by a load cell mounted on top of the plunger. (c) Close-up view of the probed volume inside the microchip.

nature of fouling contaminant build-up during $\mathrm{mAb}$ capture and elution. Our powerful approach also revealed the effectiveness of cleaning reagents offering a powerful tool to optimise CIP strategies.

\section{Results}

ATR-FTIR spectroscopy of affinity resin beads and mAb culture fluid. Probing resin by mid-infrared spectroscopy in transmission mode poses a major challenge, as a single layer of hydrated beads extinguishes most of the light, saturating the absorption. The evanescent wave produced by attenuated total reflection (ATR) allows probing of the surface layer of resin beads $(50-150 \mu \mathrm{m}$ diameter), but relies on an intimate contact between the internal reflection element and the sample. Since agarose beads are convex microspheres, only a small fraction of each bead would interact with the evanescent wave ${ }^{66}$. Hence, resin beads simply sedimented by gravity alone do not appreciably absorb in ATR mode ${ }^{36}$.

As in a standard gel chromatography column ${ }^{18}$, we loaded resin beads in a column by sedimentation (Fig. 1a) before compacting the chromatographic bed using a plunger to fill the void between the beads (Fig. 1b). The packed resin formed an intimate contact with the internal reflection element allowing measurable infrared light absorption while preserving the internal pores for the mobile phase to flow through (Fig. 1b). This in-column ATR-FTIR spectroscopic approach allows measurement of the stationary phase resin bed as well as the applied mobile phase and culture fluid.

Figure 2a compares the ATR-FTIR spectra of $50 \mathrm{mM}$ phosphate buffer and MabSelect affinity resin packed in the microchip. Because of the buffer concentration, phosphate bands at around $1100 \mathrm{~cm}^{-1}$ are much weaker than 

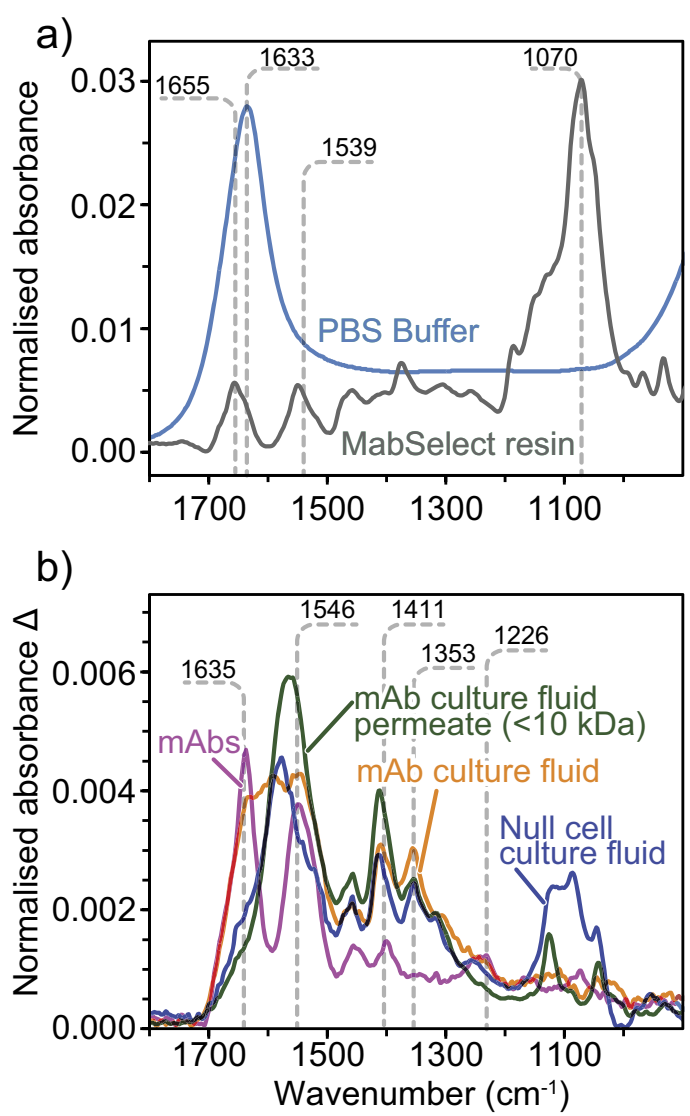

Figure 2. (a) Normalized ATR-FTIR spectra of pH 7.4 buffer (blue) and packed MabSelect Sure resin (grey). (b) ATR-FTIR difference spectra of IgG4c (orange) culture fluid compared to purified mAbs (pink), mAb culture fluid permeate $(<10 \mathrm{kDa})$ (green) and null cell culture fluid (blue).

the water bending mode at $1633 \mathrm{~cm}^{-1}$. To subtract the contribution of water, resin spectra were calculated against the background of a cell filled with buffer. The spectrum of MabSelect Protein A resin showed agarose peaks at low frequencies, including the $1070 \mathrm{~cm}^{-1}$ sugar C-O stretching mode ${ }^{36}$. Since the absorbance measured depends on the amount of resin probed by the evanescent wave ${ }^{36,65}$, ATR-FTIR spectra are affected by the contact between resin beads and the internal reflection element. ATR-FTIR spectral bands proved useful to ensure consistent packing between samples. For each measurement, the signal of the agarose peak at $1070 \mathrm{~cm}^{-1}$ was adjusted to $30 \mathrm{~mA}$, but could reach $0.2 \mathrm{~A}$ upon compression. Under $0.4 \mathrm{ml} / \mathrm{min}$ flow, the back pressure increased only from $0.07 \mathrm{MPa}$ to $0.15 \mathrm{MPa}$ after packing the resin, indicating that pores were still accessible to the buffer. The amide I and II bands, around 1652 and $1539 \mathrm{~cm}^{-1}$ respectively, reveal the presence of the bioengineered Protein A derivative affinity ligand. The reported protein ligand density was estimated as $5.6 \mathrm{mg} / \mathrm{mL}^{17}$. The negative absorbance around $1700 \mathrm{~cm}^{-1}$ originates from the displacement of water by agarose.

To assign the numerous overlapping bands of the raw culture fluid with $0.75 \mathrm{mg} / \mathrm{mL} \mathrm{mAbs}$ (orange on Fig. 2b), we separated the different constituents. A purified mAbs solution (magenta) shows clear Protein Amide I, II and III bands at 1635,1546 and $1226 \mathrm{~cm}^{-1}$ respectively ${ }^{36,49,50}$. Solutions of known mAb concentration were employed to quantify the protein concentration in the probed volume using a partial least square (PLS) method on the derivative spectra. Several side chain vibrational modes appear in the 1300 to $1500 \mathrm{~cm}^{-1}$ region including the $1411 \mathrm{~cm}^{-1} \delta \mathrm{CH}_{2}$ and $\delta_{\mathrm{s}} \mathrm{CH}_{3} 1353 \mathrm{~cm}^{-1}$ alanine or glycine component ${ }^{67}$. Using a $<10 \mathrm{kDa}$ cut off, the culture fluid permeate (green) does not show dominant amide bands, but a stronger peak at $1585 \mathrm{~cm}^{-1}$ assigned to $\delta \mathrm{NH}_{2}$ of glycine from the media feed ${ }^{67}$. The spectrum of the null-cell culture fluid appears similar to the culture fluid permeate, indicating that both contain low protein and high amino acid concentrations. The amino acid peak at $1585 \mathrm{~cm}^{-1}$ overlaps with the amide band region, interfering with the protein concentration quantification.

In-column ATR-FTIR spectroscopy of CIP. Cleaning-in-place (CIP) is commonly employed to regenerate affinity columns between purification cycles and prevent fouling contaminant build-up ${ }^{25,26,32,35,36,40}$. However, CIP alone appears to reduce binding capacity by either causing cleavage or denaturation of the Protein A ligand ${ }^{4,34,35,36}$. Instead of measuring Protein A leaching, our in-column ATR-FTIR spectroscopic approach aimed at quantifying ligand density underflow in situ during CIP while measuring the absorbance at $280 \mathrm{~nm}$. Our spectra-based PLS method quantified the in-column protein density of MabSelect resin packed in the microchip device with a detection limit of $\sim 0.1 \mathrm{mg} / \mathrm{mL}$, less than $1 \mu \mathrm{g}$ of protein in a $10 \mu \mathrm{L}$ resin probed. Collecting a background of MabSelect resin under buffer flow revealed the effect of CIP over repeated cycles. 


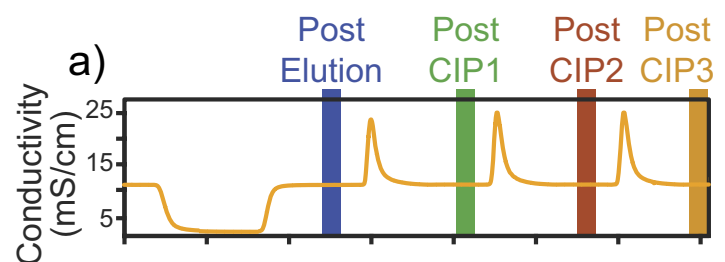

b)
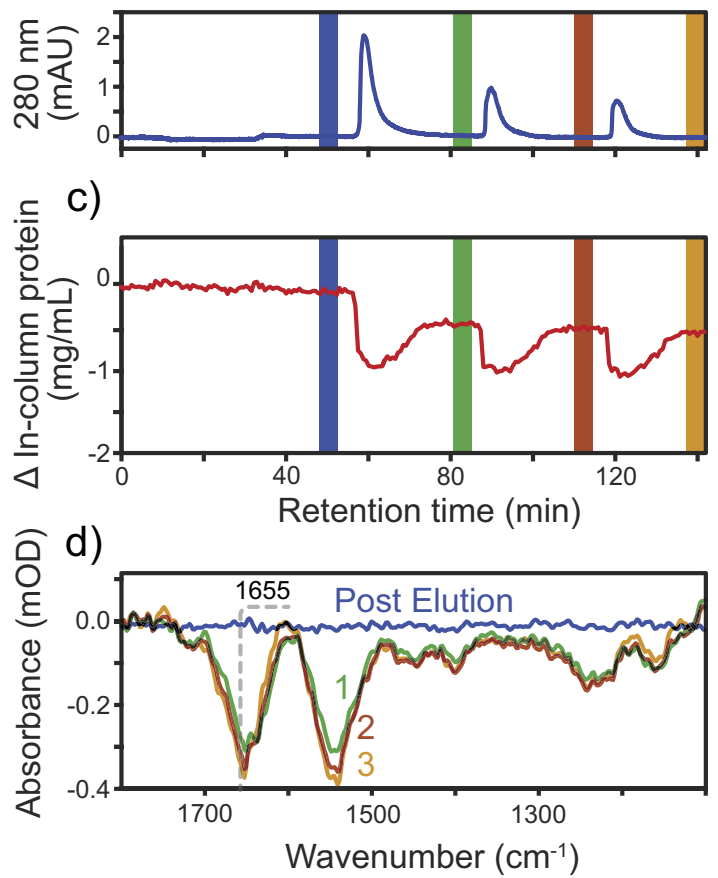

Figure 3. (a) Conductivity and (b) $280 \mathrm{~nm}$ absorbance of the mobile phase during $400 \mathrm{mM} \mathrm{NaOH} \mathrm{CIP} \mathrm{cycles.}$ (c) In-column protein concentration difference (red) calculated from ATR-FTIR spectra using PLS regression. (d) ATR-FTIR spectra after pH 3.0 elution and subsequent $400 \mathrm{mM} \mathrm{NaOH} \mathrm{CIP.}$

To compare with a typical purification protocol ${ }^{28}$, Protein A resin was first exposed to low $\mathrm{pH}$ buffer. Figure $3 \mathrm{a}$ shows the conductivity (orange) dropping when $10 \mathrm{~mL}$ of pH 3.0 buffer was added in the absence of $\mathrm{NaCl}$. Reintroducing binding buffer at $\mathrm{pH} 7.4$ and $100 \mathrm{mM} \mathrm{NaCl}$ returned the conductivity to $\sim 10 \mathrm{mS} / \mathrm{cm}$. The resin was then cleaned with three CIP cycles using $200 \mu \mathrm{L}$ of $400 \mathrm{mM} \mathrm{NaOH}$ in the absence of $\mathrm{NaCl}$, giving three conductivity peaks of $\sim 22 \mathrm{mS} / \mathrm{cm}$.

Figure $3 \mathrm{~b}$ shows the UV absorbance at $280 \mathrm{~nm}$ (blue) with only weak peaks detectable during CIP. No peaks were observed during the $\mathrm{pH} 3.0$ elution as the resin appeared stable under such conditions. During the first CIP cycle however, the absorption reached $2 \mathrm{mAU}$ while subsequent cycles resulted in peaks weaker than $1 \mathrm{~mA}$. UV absorbance measurements imply that the first exposure to $400 \mathrm{mM} \mathrm{NaOH}$ leached more protein than the following CIP cycles. Because the CIP buffer absorbed UV slightly more than the binding buffer, integrating the peak does not directly relate to the amount of ligand leached. Quantifying the amount of leaching protein during CIP can be performed using ELISA ${ }^{9}$, but the remaining ligand density concentration is challenging to quantify without measuring the resin in situ.

While UV $280 \mathrm{~nm}$ shows what flows out of the column, the ATR-FTIR spectra reveal the cumulative effect of CIP on the column. Figure $3 \mathrm{c}$ (red) shows the in-column ligand density remaining constant throughout the elution before decreasing by around $0.5 \mathrm{mg} / \mathrm{mL}$ after the first $400 \mathrm{NaOH}$ CIP. In agreement with the UV $280 \mathrm{~nm}$, subsequent CIP decreased the protein density much less. Assuming a $5.6 \mathrm{mg} / \mathrm{mL}$ ligand density ${ }^{17}$, ATR-FTIR spectra indicate that more than $90 \%$ of the ligand remained after three cycles of $400 \mathrm{mM} \mathrm{NaOH}$, equivalent to a 1.5-minute exposure. This result confirms the resistance of MabSelect to harsh CIP conditions.

Figure 3d presents the difference spectra collected after each CIP cycle with negative amide bands from protein leaching. The peak at $1655 \mathrm{~cm}^{-1}$ also corresponds to the Protein A ligand with predominantly helical structures. The lack of difference in the $\mathrm{C}-\mathrm{O}$ stretching region around $1050 \mathrm{~cm}^{-1}$ suggests that the agarose matrix remains unaffected by the CIP cycles with $400 \mathrm{mM} \mathrm{NaOH}$.

$400 \mathrm{mM} \mathrm{NaOH}$ lies in the upper range of alkaline conditions usually employed for $\mathrm{CIP}^{28}$. To represent the conditions typically used for CIP, we also tested a range of milder CIP conditions; both lower concentrations of $\mathrm{NaOH}$ or a reducing solution of thioglycerol followed by a chaotropic solution of guanidine hydrochloride, an alternative effective CIP strategy ${ }^{33}$. 


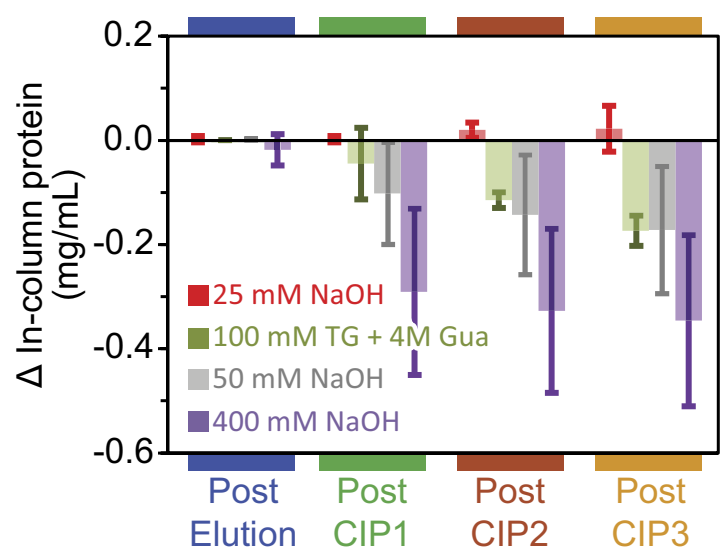

Figure 4. In-column protein concentration difference calculated from ATR-FTIR-based PLS regression (red) after elution and CIP for different conditions. The error bars represent the $95 \%$ confidence interval for $\mathrm{n}=3$.

Figure 4 shows the in-column protein concentration difference after three CIP cycles under different buffer conditions. $400 \mathrm{mM} \mathrm{NaOH}$ leached the most Protein A ligand while $50 \mathrm{mM} \mathrm{NaOH}$ and $100 \mathrm{mM}$ thioglycerol followed by $4 \mathrm{M}$ guanidine hydrochloride reduced the concentration by just $\sim 0.15 \mathrm{mg} / \mathrm{mL}$ after three cycles. Using $25 \mathrm{mM} \mathrm{NaOH}$ cycles showed no appreciable difference from the initial ligand density. Since the binding capacity should be proportional to the ligand density ${ }^{36}$, our approach could also be employed to predict the affinity to mAbs post-CIP without unpacking the column.

In-column ATR-FTIR spectroscopy of null-cell fouling. Following depth filtration, Protein A affinity chromatography usually constitutes the first purification step in the capture of antibodies. In addition to the main constituent, the mAbs culture fluid contains amino acids from the feed media and host cell proteins (HCPs), DNA and other cell debris. To investigate the effect of the different constituents, we first analysed the culture fluid from non-mAb producing null-cell lines. The total protein concentration was estimated by BCA assay to $1.01 \mathrm{mg} / \mathrm{mL}$.

Figure 5a shows the conductivity measured on the outlet during the initial CIP, flow through, elution and final CIP cycle. After the strong flow through peak $(610 \mathrm{mAU})$, no UV absorption was detected upon addition of $\mathrm{pH}$ 3.0 buffer (Fig. $5 b$ ). This result suggests that no protein bound to the resin or that they did not elute under low $\mathrm{pH}$. The difference in protein concentration determined by ATR-FTIR spectroscopy answers this question in Fig. $5 \mathrm{c}$ (red curve). Following sample injection, the in-column protein concentration rose by $\sim 0.4 \mathrm{mg} / \mathrm{mL}$ as some HCPs appear to bind to the Protein A resin. The concentration did not drop appreciably, during low $\mathrm{pH}$ elution suggesting strong affinity binding of the HCPs. Following CIP with $50 \mathrm{mM} \mathrm{NaOH}$, most of the non-eluting protein is cleared from the column, but $\sim 0.1 \mathrm{mg} / \mathrm{mL}$ of bound protein containments remained adsorbed on the resin. This result suggests that even harsher CIP conditions would be needed to completely remove all contaminant HCPs bound.

Figure 5d shows the difference in the ATR-FTIR spectra after each step, revealing the absorbance of the bound protein absorption. This contrasts with the spectra obtained for the whole null-cell culture fluid rich in amino acids shown in Fig. 2b. With a centre-of-gravity (COG) around $1631 \mathrm{~cm}^{-1}$, the amide I band position approaches that of pure mAbs suggesting a similar helical/unordered secondary structure. After CIP the amide I COG shifts to $1617 \mathrm{~cm}^{-1}$, suggesting that the remaining adsorbed proteins adopt a secondary structure with a higher $\beta$-sheet content, as previously reported for insoluble aggregates ${ }^{16,49,50}$. Only protein bands were observed, suggesting that binding contaminants were primarily proteins rather than lipids or DNA which should be clearly differentiated based on their unique IR bands.

Figure 6 shows the difference in protein concentration in the column measured after binding, elution and CIP for three sample loadings. After loading an equivalent of $5 \mu \mathrm{g}$ of HCP per $\mu \mathrm{L}$ of resin, the increase in protein concentration post-binding is barely detectable, but at $25 \mu \mathrm{g} / \mu \mathrm{L}$ the in-column protein concentration rose appreciably to $\sim 0.4 \mathrm{mg} / \mathrm{mL}$. Injecting $101 \mu \mathrm{g} / \mu \mathrm{L}$ of $\mathrm{HCP}$ did not appear to increase binding much further, suggesting that the amount might have exceeded the resin's capacity to bind HCP contaminants. Low $\mathrm{pH}$ elution did not appear to decrease the in-column concentration much for all loads tested, confirming the strength of such interactions. CIP with $50 \mathrm{mM} \mathrm{NaOH}$ seems to have removed most $\mathrm{HCP}$ at $5 \mu \mathrm{g}$, but did not remove half of the adsorbed protein at either the 25 or $101 \mu \mathrm{g}$ loads. These results, therefore, suggest that some HCP species strongly associate to the resin and remain adsorbed under typical CIP conditions. Such proteins could thus build-up over repeated cycles and restrict access to the Protein A ligand.

In situ analysis of resin fouling. Previous reports suggest that full antibodies and mAbs fragments are also involved in Protein A resin fouling. After binding to the ligand, mAbs can bind HCPs via their antigen-binding Fab fragment or aggregate inside the porous matrix during elution ${ }^{29}$. To study the fouling process of Protein A affinity resin, our in-column ATR-FTIR spectroscopic setup measured mabSelect resin during purification and CIP of full culture fluid containing $0.75 \mathrm{mg} / \mathrm{mL} \mathrm{mAbs}$. 


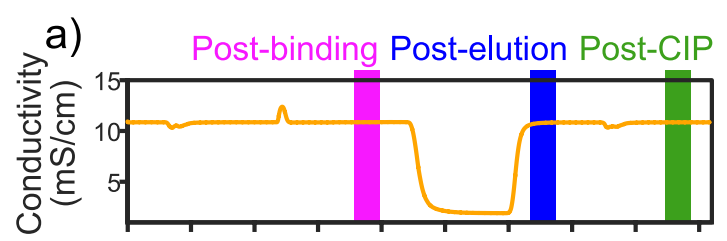

b)
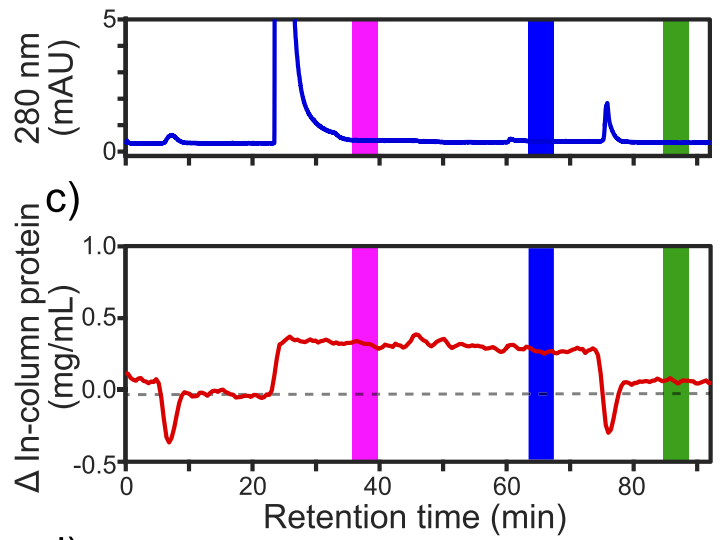

d)

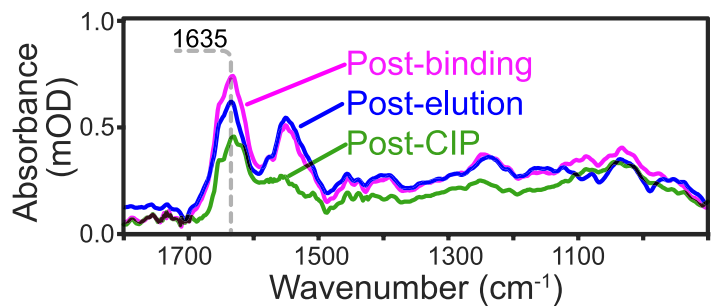

Figure 5. (a) Conductivity and (b) $280 \mathrm{~nm}$ absorbance of the mobile phase during purification of $500 \mu \mathrm{L}$ of null-cell culture fluid and $50 \mathrm{mM} \mathrm{NaOH} \mathrm{CIP} \mathrm{cycles.} \mathrm{(c)} \mathrm{In-column} \mathrm{protein} \mathrm{concentration} \mathrm{calculated} \mathrm{from}$ ATR-FTIR spectra using PLS regression during purification and $50 \mathrm{mM} \mathrm{NaOH} \mathrm{CIP.} \mathrm{(d)} \mathrm{ATR-FTIR} \mathrm{spectra} \mathrm{after}$ culture fluid binding, $\mathrm{pH} 3.0$ elution and $50 \mathrm{mM} \mathrm{NaOH}$ CIP.

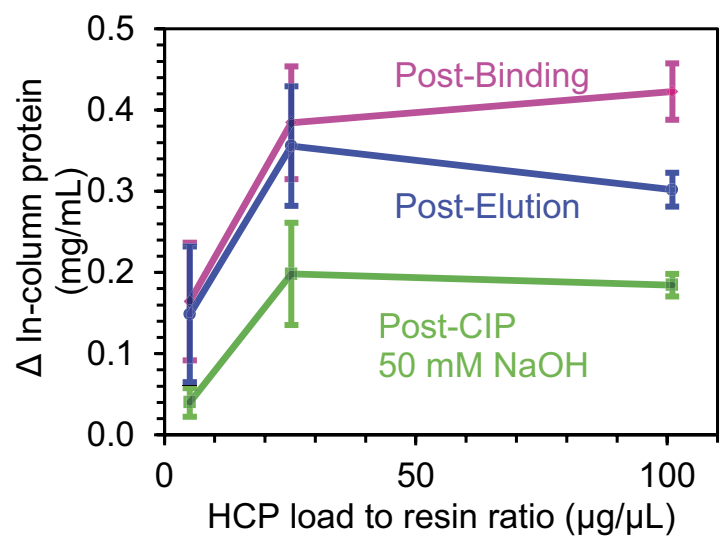

Figure 6. The difference in protein concentration determined by ATR-FTIR spectroscopy: post-binding (magenta), post-elution (blue) and post-CIP (green) as a function of HCP load. The error bars represent the $95 \%$ confidence interval for $\mathrm{n}=3$.

Following a first CIP cycle to condition the Protein A resin, Fig. 7a shows the conductivity measured during binding, elution and CIP. Because of the higher salt concentration in the culture fluid, injecting $500 \mu \mathrm{L}$ of sample increased the conductivity before stabilising after the flow through peak. Compared to the binding buffer, 

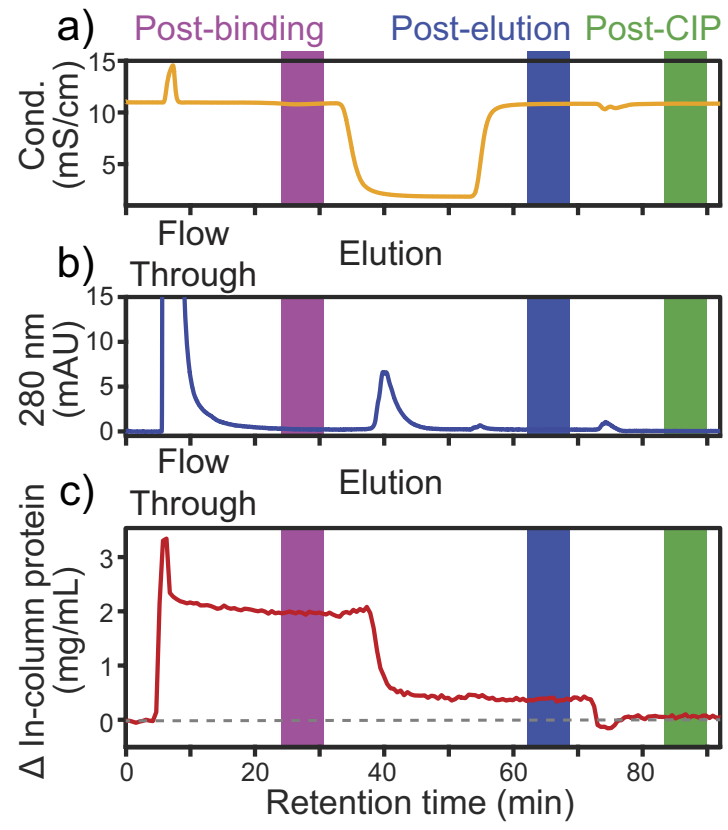

d)

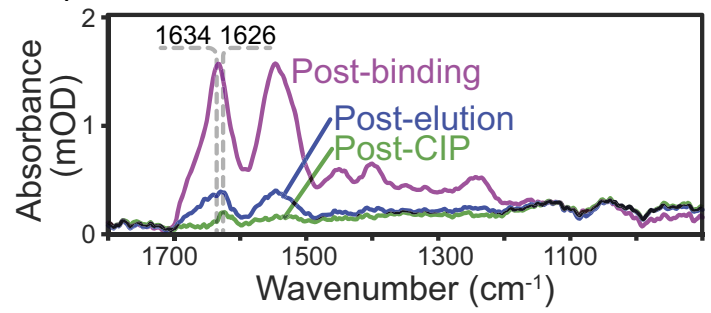

Figure 7. (a) Conductivity (orange) and (b) $280 \mathrm{~nm}$ absorbance (blue) of the mobile phase during purification of mAb culture fluid and $50 \mathrm{mM} \mathrm{NaOH} \mathrm{CIP} \mathrm{cycles.} \mathrm{(c)} \mathrm{In-column} \mathrm{protein} \mathrm{concentration} \mathrm{difference} \mathrm{(red)}$ calculated from ATR-FTIR spectra using PLS regression during purification and $50 \mathrm{mM} \mathrm{NaOH} \mathrm{CIP.} \mathrm{(d)} \mathrm{ATR-}$ FTIR spectra after mAb binding, $\mathrm{pH} 3.0$ elution and $50 \mathrm{mM} \mathrm{NaOH} \mathrm{CIP.}$

the conductivity dropped upon addition of lower salt content elution buffer. The conductivity remained almost constant when $50 \mathrm{mM} \mathrm{NaOH}$ CIP buffer was added as the salt concentration was similar to the binding buffer.

Since $\mathrm{mAbs}$ bound to the Protein A resin, Fig. $7 \mathrm{~b}$ shows a clear elution peak, reaching $6 \mathrm{mM}$ under low $\mathrm{pH}$ buffer. When injecting $500 \mu \mathrm{L}$ of culture fluid ( $38 \mathrm{mg}$ of $\mathrm{mAb}$ per $\mathrm{mL}$ of resin), the area of the peak however represents only $\sim 1 \%$ of the integrated $280 \mathrm{~nm}$ absorbance of the flow through, capturing only a small fraction of the mAbs product. The small column volume $(10 \mu \mathrm{L})$ and high load could be responsible for the low capture ratio. Moreover at $0.4 \mathrm{~mL} / \mathrm{min}$, the residence time was only 1.25 minutes, at the lower end of typical values ( 1 to $6 \mathrm{~min})^{17}$. The small geometry of the microcolumn would also make the wall effect greater ${ }^{46}$, increasing the linear velocity on the IRE surface. Cleaning the column with $50 \mathrm{mM} \mathrm{NaOH}$ resulted in a weak peak of merely $1 \mathrm{~mA}$, indicating that some other proteins were removed through CIP.

As shown on Fig. 7c, the protein concentration quantified by ATR-FTIR spectroscopy complements UV $280 \mathrm{~nm}$ detection by revealing only what remains in the column after each step instead of what flows through. Probing the stationary phase had the benefit of allowing the subtraction of the bands from the amino acids in the culture fluid and thus measurement of only protein bound to the affinity resin. Following a $38 \mu \mathrm{g} / \mu \mathrm{L}(\mathrm{mAb} /$ resin) culture fluid injection, the in-column protein concentration increased to $\sim 2 \mathrm{mg} / \mathrm{mL}$ indicating that Protein A effectively bound to the Protein A resin. Application of the low $\mathrm{pH}$ buffer resulted in elution of most of the protein, but a sizable amount remained bound post-elution. These irreversibly bound proteins could be responsible for resin fouling and binding capacity decay. Applying $50 \mathrm{mM} \mathrm{NaOH}$ cleared most of the post-elution proteins demonstrating the efficiency of CIP.

Figure 7d shows the differences in the ATR-FTIR spectra after each step. As expected, the spectrum after binding resembles purified $\mathrm{mAbs}$ rather than culture fluid since the mAbs bound to the resin in the probed volume. After flowing buffer at $\mathrm{pH} 3.0$ through, the in-column concentration dropped while the amide I band shifted to lower wavenumbers, suggesting that non-eluting proteins contained slightly more $\beta$-sheet than the $\mathrm{mAb}$. After $50 \mathrm{mM} \mathrm{NaOH}$ CIP even less protein remains. With an even lower amide I band wavenumber, the difference spectra post-CIP indicates that the remaining fouling proteins are mainly comprised of $\beta$-sheet rich aggregates, in agreement with previous studies ${ }^{16,68}$. 


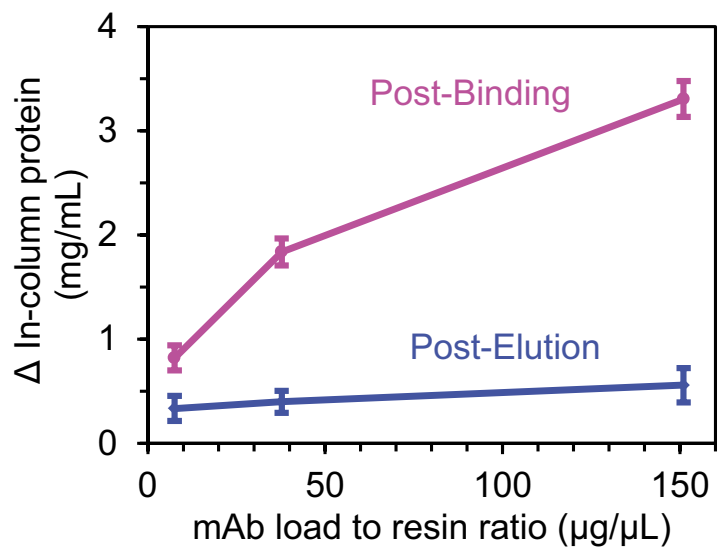

Figure 8. In-column protein concentration difference calculated from ATR-FTIR spectra using PLS regression post-binding (magenta), post-elution (blue) and post-CIP $50 \mathrm{mM} \mathrm{NaOH}$ as a function of $\mathrm{mAbs}$ load. The error bars represent the $95 \%$ confidence interval for $\mathrm{n}=3$.

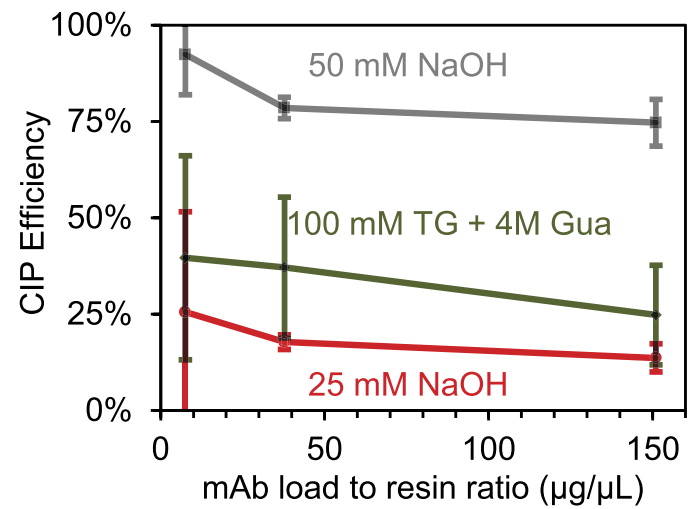

Figure 9. The efficiency of CIP at removing non-eluting protein as a function of $\mathrm{mAb}$ load. The error bars represent the two standard deviation interval for $\mathrm{n}=3$.

Figure 8 shows the difference in protein concentration determined by ATR-FTIR spectroscopy post-binding and post-elution for three different $\mathrm{mAb}$ samples. As the $\mathrm{mAb}$ breaks through when the load exceeds the binding capacity $(\sim 30 \mathrm{mg} / \mathrm{mL})^{17}$, the in-column protein concentration will plateau relative to the amount of $\mathrm{mAb}$ loaded. At $8 \mathrm{mg} / \mathrm{mL}$ of $\mathrm{mAbs}$, the in-column protein concentration reaches $1 \mathrm{mg} / \mathrm{mL}$ after binding while loading $151 \mathrm{mg} / \mathrm{mL}$ only increased the in-column concentration to $\sim 3.5 \mathrm{mg} / \mathrm{mL}$. The proportion of irreversibly bound protein post-elution appears to decrease slightly with load from $\sim 30$ to $20 \%$. Competition between mAbs and HCPs for the resin binding sites could explain this result. In addition to sodium hydroxide solutions, there are a range of different CIP protocols which have also proved effective at removing protein aggregates ${ }^{28,69}$.

Figure 9 a reveals the efficiency of three CIP procedures in removing bound protein which failed to elute at $\mathrm{pH}$ 3.0. At low load, $50 \mathrm{mM} \mathrm{NaOH}$ proved the most effective by removing almost all non-eluting proteins bound to the column while other protocols were less than $25 \%$ effective. Under greater load, the efficiency of $50 \mathrm{mM} \mathrm{NaOH}$ dropped to $\sim 80 \%$ but remained much more effective than $25 \mathrm{mM} \mathrm{NaOH}$ and $100 \mathrm{mM}$ thioglycerol (TG) followed by $4 \mathrm{M}$ guanidine hydrochloride (Gua). At a load much greater than the reported binding capacity $(1510 \mu \mathrm{g})$, the efficacy of milder CIP buffers dropped to less than $10 \%$. These results thus clearly reveal the inability of such conditions to remove contaminant proteins which may contribute to binding capacity decay.

\section{Discussion}

Here we describe direct coupling of infrared spectroscopy with affinity chromatography for the first time, as a means of better understanding Protein A based affinity chromatography of mAbs. Our in-column ATR-FTIR spectroscopic setup allows direct analysis of the stationary phase during purification. This was complemented by the measurement of the mobile phase with UV 280 and conductivity using a standard protein purification system. The micro-scale column setup uses very little resin allowing us to very efficiently assess the effects of a number of different purification conditions and cleaning protocols. Since organic molecules absorb infrared light at specific frequencies, ATR-FTIR spectroscopy can differentiate between the different molecules within the column without the need for labelling. This allows differentiation between the agarose beads, protein, DNA and lipid in any sample. This approach provided an opportunity to characterise precisely what contaminants are fouling the resin and 
potentially leading to reduced binding capacity. When flowing either null-cell culture fluid from a non-antibody expressing cell line or cell culture fluid containing mAbs through the resin, ATR-FTIR detected contaminant protein binding to the resin. By measuring the stationary phase, our approach also revealed host cell proteins (HCPs) remaining after low $\mathrm{pH}$ elution for both samples. In the case of the null-cell culture fluid, over $0.5 \mathrm{mg} / \mathrm{mL}$ of $\mathrm{HCP}$ bound to the resin which did not elute at low $\mathrm{pH}$.

Notably, larger quantities of contaminant bound when mAbs were present in the applied sample. A previous study by Zhang et al. hypothesised that $\mathrm{mAb}$ binding to the resin could undergo conformational change, forming a partially unfolded intermediate ${ }^{29}$. The $\mathrm{mAb}$ may then expose hydrophobic domains more likely to associate with lipophilic $\mathrm{HCPs}^{29}$. This association could then result in the formation of large HCP-mAb complexes prone to aggregating within the porous resin matrix. Infrared spectra collected after elution and CIP support this hypothesis by indicating that the remaining protein contains a larger proportion of $\beta$-sheets, known to form hydrophobic domains ${ }^{36,50}$. Identification of the individual contaminating species did not form part of this study. It is possible however that one of the contaminants is histone previously shown bind to protein A, reducing the dynamic binding capacity ${ }^{8}$.

Interestingly, our analysis did not detect any contaminant lipid or DNA. Thus future efforts to optimise the protein A purification process need to focus primarily on removal of contaminating proteins.

Our approach also allowed analysis of the effects of CIP protocols used to prevent resin fouling. By testing CIP alone, we were able to quantify the Protein A leaching from unused MabSelect SuRe resin over repeated cleaning cycles. The first exposure to CIP buffer leached much more ligand than subsequent cycles. While the underlying cause remains unclear, it is possible that the first CIP cycle ligand causes leaching of more weakly bound Protein A molecules. Hence, to avoid misinterpreting leaching protein A as cleared fouling contaminants in the mass balance calculation, we performed a CIP before exposing MabSelect resin to culture fluid.

We found that CIP cleared most of the contaminant protein although the efficiency was dependent on the CIP protocol used. However, even the most effective method tested, the standard $50 \mathrm{mM} \mathrm{NaOH}$ treatment, did not return the protein concentration to its initial value. Hence, there is scope for the development of more effective CIP protocols to reduce contaminant binding. Harsher CIP conditions are more effective but as we showed recently these reduce binding capacity by degrading the ligand ${ }^{26,36}$. Thus our in-column sensing approach could help optimization of the CIP protocol to achieve the best compromise between column cleaning and ligand degradation.

Our microchip setup demonstrated the usefulness of an in-column ATR-FTIR spectroscopic approach. It is important to note that the very small scale of the column could have accentuated the wall effect on the flow profile ${ }^{46,48}$. Further studies are required to confirm our findings in large scale set ups. However, it is anticipated that our approach could be easily be applied to full-scale chromatographic processes via the embedding of sensors in the column casing. Instead of using MCT detectors requiring liquid nitrogen cooling, the more common and affordable DTGS detectors could be employed to monitor purification processes. The angle of incidence of the infrared light in the diamond ATR accessory could be adjusted to optimise the penetration depth and the resin signal ${ }^{65,70}$. The addition of ATR-FTIR spectroscopic sensors to gel chromatographic columns offers many advantages to process analytical technology (PAT). Stationary phase composition monitoring could track the mass balance to predict binding capacity and optimize CIP protocols to individual feeds. Monitoring protein contaminant build-up with in-column PAT could also prove useful for quality assurance purposes. Beyond research and development, adjusting the CIP condition to the fouling state of the column could enhance resin lifespan and reduce resin replacement rate.

The application of non-invasive, label-free ATR-FTIR spectroscopy revealed that loss of binding capacity of the column is thus a combination of irreversible binding of host cell proteins with no detectable contribution to fouling from lipids or DNA. In addition, the approach has allowed a detailed comparison of the different CIP protocols. Even minor alterations in the purification and cleaning protocols could result in a significant cost saving in the production of therapeutic mAbs.

\section{Method}

Microchip for In-column ATR-FTIR spectroscopy. The microfluidic device was encased in a laser-cut PMMA sheet assembly with bolts. The microchip was made of a Sylgard ${ }^{\circledR} 184$ poly-(dimethylsiloxane) (PDMS) elastomeric substrate (Dow Corning Corporation, Midland, MI, USA). To prevent protein adsorption, the PDMS elastomer contained $1.5 \% \%$ poly(dimethylsiloxane-ethylene oxide) before casting. The hydrophilic elastomer was cast from a PMMA 3D printed negative master made by multijet modeling with a layer resolution of $16 \mu \mathrm{m}$ (Shapeways, New York, USA).

Figure 1a shows the microfluidic assembly containing the microchip with an inlet and outlet. A funnel was attached to the top port and buffer pumped through the cell to push the air out. The microchip was packed with $10 \mu \mathrm{L}$ of sedimented MabSelect Sure resin (GE healthcare, Little Chalfont, UK) constituted of porous cross-linked agarose beads ranging from 20 to $160 \mu \mathrm{m}$ in diameter. To ensure that the resin beads filled the entire column cavity, buffer was pumped through the top loading port to push the resin down.

Subsequently, the funnel was replaced by the plunger (Fig. 1b). The resin was slowly packed under $0.4 \mathrm{~mL} / \mathrm{min}$ flow while collecting ATR-FTIR spectra until the absorbance of the main agarose band at $1060 \mathrm{~cm}^{-1}$ reached $50 \mathrm{~mA}$. A 32 scan ATR-FTIR spectrum of the packed resin bed under $0.4 \mathrm{~mL} / \mathrm{min}$ was collected as a reference background. The back pressure inside the device typically did not exceed $0.18 \mathrm{MPa}$ under $0.4 \mathrm{~mL} / \mathrm{min}$ flow. After completing the LC-IR in situ measurements, a new background single channel was collected before removing the plunger under flow. The unpacked resin beads flowed out of the column cavity before another 32 scan ATR-FTIR spectrum was collected.

The close-up view of Fig. 1c shows the nine channels with a width of $40 \mu \mathrm{m}$ feeding the mobile phase into the microchip cavity of 1600 by 1200 by $300 \mu \mathrm{m}$ constituting the micro-scale column. The base of the 
chromatographic column was probed by the evanescent wave generated from the internal reflection element (IRE) of the diamond attenuated total reflection (ATR) accessory (Specac, Orpington, UK). Diamond is an ideal IRE material as it is both resistant to corrosion and hard. A $45^{\circ}$ angle of incidence resulted in a $\sim 1.2 \mu \mathrm{m}$ depth of penetration ${ }^{65,70}$. The walls of the microfluidic device were not within the probed volume as no peaks for PDMS were observed. ATR-FTIR pectra were collected using a Tensor 27 FTIR spectrometer (Bruker, Billeria, USA) equipped with globar silicon carbide infrared source, a $\mathrm{KBr}$ beam splitter and a liquid nitrogen cooled single-element MCT detector. Data were collected with a spectral resolution of $4 \mathrm{~cm}^{-1}$. Spectra were the result of co-adding 32 scans that required 37 seconds.

The mobile phase was pumped through the microfluidic device at $0.4 \mathrm{~mL} / \mathrm{min}$ using an Akta Prime liquid chromatography instrument operated by PrimeView (GE Healthcare, Little Chalfont, UK). The $10 \mathrm{mM}$ phosphate binding buffer was adjusted to $\mathrm{pH} 7.4$ and contained $100 \mathrm{mM} \mathrm{NaCl}$. The $\mathrm{pH} 3.0$ elution buffer did not have added $\mathrm{NaCl}$ to reduce binding affinity to mAbs. Sodium hydroxide solutions of $25-400 \mathrm{mM}$ were used for CIP. To replace depth filtration typically used for large scale purification ${ }^{2,11}$, the culture fluid samples were filtered through $0.4 \mu \mathrm{m}$ syringe filter before injection to remove large particulates.

mAb sample preparation. The chimeric B72.3 immunoglobulin G gamma 4 (IgG4) was expressed in a Glutamine Synthetase Chinese Hamster Ovary (GS-CHO) cell line (Lonza Biologics, Basel, Switzerland). Cultures were maintained in protein-free, serum-free chemically defined CD-CHO medium (Invitrogen, UK) with $25 \mathrm{mM}$ L-Methionine sulfoximine (Sigma, UK) at $36.5^{\circ} \mathrm{C}$ with $8 \% \mathrm{CO}_{2}$ air while stirred on an orbital shaker at $140 \mathrm{rpm}$. In batch cultures conducted in $1 \mathrm{~L}$ Erlenmeyer flasks with a working volume of $300 \mathrm{~mL}$, cells were subcultured every 3 or 4 days to achieve a target seeding density of $2 \times 10^{5}$ cells $/ \mathrm{mL}$. The $\mathrm{mAb}$ concentration in the media samples was quantified by ELISA (Montgomery, TX, US) and UV spectrophotometry using a Nanodrop Lite system (Thermo, Wilmington, DE, USA) and a $\mathrm{E}^{1 \%}$ of 13.7. Samples were then stored at $-80^{\circ} \mathrm{C}$ until further use.

The $\mathrm{mAb}$ standards were defrosted and filtered through a $0.45 \mu \mathrm{m}$ filter disk to remove large particulates. Subsequently, the culture fluid containing the product protein and host cell proteins was either used directly in the set-up described above or the mAb was purified using affinity chromatography with a MabSelect SuRe Protein A column (GE Life Sciences, UK). The concentration of $\mathrm{mAb}$ standard solutions were quantified by UV absorption at $280 \mathrm{~nm}$ with a Nano drop Lite (Thermo, USA) using $\mathrm{E}^{1 \%}$ of 13.7 , corresponding to $260.4 \mathrm{~mA} / \mathrm{mL}$ on the FPLC chromatograms. The $0.75 \mathrm{mg} / \mathrm{mL} \mathrm{mAb}$ concentration was calculated from the eluted fraction after Protein A affinity chromatography. The total protein content in the culture fluid was quantified using the bicinchoninic acid (BCA) assay by measuring the $562 \mathrm{~nm}$ absorbance compared to BSA standard solutions. The null-cell culture fluid had a total protein concentration of $1.02 \mathrm{mg} / \mathrm{mL}$ while the $\mathrm{mAb}$ culture fluid had a concentration of $0.75 \mathrm{mg} / \mathrm{mL}$.

Resin fouling measured by in-column ATR-FTIR spectroscopy. A background spectrum was collected during equilibration to subtract the absorbance from the hydrated resin bed. ATR-FTIR spectra were collected continuously during the purification and cleaning-in-place cycles. The LC-IR purification of IgG, $500 \mu \mathrm{L}$ of raw culture fluid sample was pumped from the injection loop before washing unbound IgG with $10 \mathrm{~mL}$ (1000 CVs) of binding buffer. Bound mAb was eluted with pH 3.0. For CIP cycles, $200 \mu \mathrm{L}$ of 25, 50 or $400 \mathrm{mM}$ $\mathrm{NaOH}$ or $100 \mathrm{mM}$ thioglycerol followed by $4 \mathrm{M}$ guanidine hydrochloride were flowed through the column prior to equilibration with $10 \mathrm{~mL}$ of binding buffer.

Data analysis. ATR-FTIR spectra were exported from Opus (Bruker, Billeria, USA) and chromatograms exported from Unicorn (GE healthcare, Little Chalfont, UK) to MATLAB (MatWorks, Natick, MA, USA). Using a custom made MATLAB code, spectra were offset using the average absorbance values between 1870 and $1840 \mathrm{~cm}^{-1}$. Spectra kinetics were averaged using a mobile window of 4 spectra of 32 scans. A 5-point smoothing function was applied on the spectra presented on Fig. 5. The adsorbed protein concentration and resin $\mathrm{pH}$ were quantified using a partial least square (PLS) regression based on concentration standards. Spectra of purified IgG solutions of $0.5,1,2,4$ and $8 \mathrm{mg} / \mathrm{mL}$ were used for the adsorbed protein concentration curve. The partial least square (PLS) method used the 1800 to $1400 \mathrm{~cm}^{-1}$ region to quantify adsorbed protein concentration (PLS model $\left.\mathrm{R}^{2}=0.89\right)$. Finally, the in-column ATR-FTIR spectroscopic data, conductivity and UV $280 \mathrm{~nm}$ data were coupled in a database using time as common variable.

\section{References}

1. Reichert, J. M. Which are the antibodies to watch in 2013? MAbs 5, 1-4, doi: 10.4161/mabs.22976 (2013)

2. Kelley, B. Very large scale monoclonal antibody purification: The case for conventional unit operations. Biotechnol. Prog. 23, 995-1008, doi: 10.1021/bp070117s (2007).

3. Butler, M. D., Kluck, B. \& Bentley, T. DNA spike studies for demonstrating improved clearance on chromatographic media. Journal of Chromatography A 1216, 6938-6945 (2009).

4. Flatman, S., Alam, I., Gerard, J. \& Mussa, N. Process analytics for purification of monoclonal antibodies. Journal of Chromatography. 848, 79-87 (2007).

5. Grachev, V., Magrath, D. \& Griffiths, E. WHO requirements for the use of animal cells as in vitro substrates for the production of biologicals (Requirements for biological susbstances no. 50). Biologicals: journal of the International Association of Biological Standardization 26, 175-193 (1998).

6. Zhang, S. et al. Structural and functional characteristics of virgin and fouled protein A MabSelect resin cycled in a monoclonal antibody purification process. Biotechnol. Bioeng. 113, 367-375 (2016).

7. Gijsbers, L. et al. Quantification of residual host cell DNA in adenoviral vectors produced on PER. C6 ${ }^{\circledR}$ cells. Human gene therapy 16, 393-398 (2005)

8. Nian, R. et al. Advance chromatin extraction improves capture performance of protein A affinity chromatography. Journal of Chromatography A. 1431, 1-7 (2016).

9. Hogwood, C. E., Bracewell, D. G. \& Smales, C. M. Host cell protein dynamics in recombinant CHO cells: impacts from harvest to purification and beyond. Bioengineered 4, 288-291, doi: 10.4161/bioe.23382 (2013). 
10. Shukla, A. A. et al. Demonstration of robust host cell protein clearance in biopharmaceutical downstream processes. Biotechnol. Prog. 24, 615-622, doi: 10.1021/bp070396j (2008).

11. Bracewell, D. et al. Impact of clarification strategy on chromatographic separations: Pre-processing of cell homogenates. Biotechnol. Bioeng. 100, 941-949 (2008).

12. Brorson, K., Brown, J., Hamilton, E. \& Stein, K. E. Identification of protein A media performance attributes that can be monitored as surrogates for retrovirus clearance during extended re-use. Journal of Chromatography A. 989, 155-163 (2003).

13. Ahuja, S. Handbook of bioseparations. (2000).

14. Close, E. J., Salm, J. R., Iskra, T., Sorensen, E. \& Bracewell, D. G. Fouling of an Anion Exchange Chromatography Operation in a Monoclonal Antibody Process: Visualization and Kinetic Studies. Biotechnol. Bioeng. 110, 2425-2435, doi: 10.1002/bit.24898 (2013).

15. Liu, H. F. et al. Exploration of overloaded cation exchange chromatography for monoclonal antibody purification. Journal of Chromatography A 1218, 6943-6952, doi: 10.1016/j.chroma.2011.08.008 (2011).

16. Shukla, A. A., Hubbard, B., Tressel, T., Guhan, S. \& Low, D. Downstream processing of monoclonal antibodies-application of platform approaches. Journal of Chromatography B 848, 28-39 (2007).

17. Johansson, H. J., ljunglöf, A. \& Palmgren, R. (Google Patents, 2011)

18. Amersham Pharmacia, B. Antibody purification: handbook. (Amersham Pharmacia Biotech, 2000).

19. Hahn, R., Schlegel, R. \& Jungbauer, A. Comparison of protein A affinity sorbents. J. Chromatogr. B 790, 35-51, doi: 10.1016/s15700232(03)00092-8 (2003)

20. Rathore, A. S., Pathak, M., Ma, G. J. \& Bracewell, D. G. Re-use of Protein A Resin: Fouling and Economics. Biopharm. Int. 28, 28-33 (2015).

21. Ng, C. K. S., Osuna-Sanchez, H., Valery, E., Sorensen, E. \& Bracewell, D. G. Design of high productivity antibody capture by protein A chromatography using an integrated experimental and modeling approach. J. Chromatogr. B 899, 116-126, doi: 10.1016/j. jchromb.2012.05.010 (2012)

22. Pollock, J. et al. Optimising the design and operation of semi-continuous affinity chromatography for clinical and commercial manufacture. Journal of Chromatography A 1284, 17-27 (2013).

23. Raven, N. et al. Scaled-up manufacturing of recombinant antibodies produced by plant cells in a 200-L orbitally-shaken disposable bioreactor. Biotechnol. Bioeng. 112, 308-321 (2015).

24. Follman, D. K. \& Fahrner, R. L. Factorial screening of antibody purification processes using three chromatography steps without protein A. Journal of Chromatography A 1024, 79-85 (2004).

25. Shukla, A. A. \& Hinckley, P. Host Cell Protein Clearance During Protein A Chromatography: Development of an Improved Column Wash Step. Biotechnol. Prog. 24, 1115-1121, doi: 10.1021/bp.50 (2008).

26. Jiang, C. P., Liu, J., Rubacha, M. \& Shukla, A. A. A mechanistic study of Protein A chromatography resin lifetime. Journal of Chromatography A 1216, 5849-5855, doi: 10.1016/j.chroma.2009.06.013 (2009).

27. Hahn, R., Shimahara, K., Steindl, F. \& Jungbauer, A. Comparison of protein A affinity sorbents III. Life time study. Journal of Chromatography A 1102, 224-231, doi: 10.1016/j.chroma.2005.10.083 (2006)

28. Gronberg, A., Eriksson, M., Ersoy, M. \& Johansson, H. J. A tool for increasing the lifetime of chromatography resins. Mabs 3, 192-202, doi: $10.4161 /$ mabs.3.2.14874 (2011).

29. Zhang, S. et al. Nature of foulants and fouling mechanism in the Protein A MabSelect resin cycled in a monoclonal antibody purification process. Biotechnol. Bioeng. 113, 141-149 (2016)

30. Mazzer, A. R., Perraud, X., Halley, J., O’Hara, J. \& Bracewell, D. G. Protein A chromatography increases monoclonal antibody aggregation rate during subsequent low $\mathrm{pH}$ virus inactivation hold. Journal of Chromatography A 1415, 83-90 (2015).

31. Hober, S., Nord, K. \& Linhult, M. Protein A chromatography for antibody purification. Journal of Chromatography B 848, 40-47 (2007).

32. Hale, G., Drumm, A., Harrison, P. \& Phillips, J. Repeated cleaning of protein A affinity column with sodium hydroxide. Journal of immunological methods 171, 15-21 (1994).

33. Ladiwala, A. \& Pieracci, J. (Google Patents, 2015).

34. Carter-Franklin, J. N., Victa, C., McDonald, P. \& Fahrner, R. Fragments of protein A eluted during protein A affinity chromatography. Journal of Chromatography A 1163, 105-111, doi: 10.1016/j.chroma.2007.06.012 (2007).

35. Wang, L. et al. A safe, effective, and facility compatible cleaning in place procedure for affinity resin in large-scale monoclonal antibody purification. Journal of Chromatography A 1308, 86-95, doi: 10.1016/j.chroma.2013.07.096 (2013).

36. Boulet-Audet, M., Byrne, B. \& Kazarian, S. G. Cleaning-in-place of immunoaffinity resins monitored by in situ ATR-FTIR spectroscopy. Anal Bioanal Chem 407, 7111-7122, doi: 10.1007/s00216-015-8871-3 (2015).

37. Clarke, S. Propensity for spontaneous succinimide formation from aspartyl and asparaginyl residues in cellular proteins. Int. J. Pept. Prot. Res. 30, 808-821 (1987).

38. Nilsson, M. R., Driscoll, M. \& Raleigh, D. P. Low levels of asparagine deamidation can have a dramatic effect on aggregation of amyloidogenic peptides: Implications for the study of amyloid formation. Protein Sci. 11, 342-349, doi: Doi 10.1110/Ps.48702 (2002).

39. Bak, H. \& Thomas, O. Evaluation of commercial chromatographic adsorbents for the direct capture of polyclonal rabbit antibodies from clarified antiserum. Journal of Chromatography B 848, 116-130 (2007).

40. Hou, Y., Jiang, C., Shukla, A. A. \& Cramer, S. M. Improved Process Analytical Technology for Protein A Chromatography Using Predictive Principal Component Analysis Tools. Biotechnol. Bioeng. 108, 59-68, doi: 10.1002/bit.22886 (2011).

41. Tarrant, R. D. R., Velez-Suberbie, M. L., Tait, A. S., Smales, C. M. \& Bracewell, D. G. Host cell protein adsorption characteristics during protein a chromatography. Biotechnol. Prog. 28, 1037-1044, doi: 10.1002/btpr.1581 (2012).

42. Hansen, R., Dickson, A. J., Goodacre, R., Stephens, G. M. \& Sellick, C. A. Rapid characterization of N-linked glycans from secreted and gel-purified monoclonal antibodies using MALDI-ToF mass spectrometry. Biotechnol. Bioeng. 107, 902-908 (2010).

43. Wirz, R. Molecular insight into chromatographic and catalytic interfaces by in situ ATR-IR spectroscopy PhD thesis, Swiss Federal Institute of Technology (ETH) (2007).

44. Chen, B., Ye, Q., Zhou, K. \& Wang, Y. Adsorption and separation of HCV particles by novel affinity aptamer-functionalized adsorbents. Journal of Chromatography B 1017, 174-181 (2016).

45. Shapiro, M. S., Haswell, S. J., Lye, G. J. \& Bracewell, D. G. Microfluidic Chromatography for Early Stage Evaluation of Biopharmaceutical Binding and Separation Conditions. Separation Science and Technology 46, 185-194, doi: 10.1080/01496395. 2010.511641 (2011).

46. Shapiro, M. S., Haswell, S. J., Lye, G. J. \& Bracewell, D. G. Design and Characterization of a Microfluidic Packed Bed System for Protein Breakthrough and Dynamic Binding Capacity Determination. Biotechnol. Prog. 25, 277-285, doi: 10.1021/bp.99 (2009).

47. Holland, D., Sederman, A., Mantle, M., Gladden, L. \& Middelberg, A. Quantitative magnetic resonance imaging of urea and lysozyme in protein chromatography. Journal of Chromatography A 1033, 311-319 (2004)

48. Astrath, D.-U., Lottes, F., Vu, D. T., Arlt, W. \& Stenby, E. H. Experimental investigation of liquid chromatography columns by means of computed tomography. Adsorption 13, 9-19 (2007).

49. Boulet-Audet, M., Byrne, B. \& Kazarian, S. G. High-Throughput Thermal Stability Analysis of a Monoclonal Antibody by Attenuated Total Reflection FT-IR Spectroscopic Imaging. Anal Chem 86, 9786-9793, doi: 10.1021/ac502529q (2014).

50. Goormaghtigh, E., Cabiaux, V. \& Ruysschaert, J. M. Determination of soluble and membrane protein structure by Fourier transform infrared spectroscopy. III. Secondary structures. Sub-cellular biochemistry 23, 405-450 (1994). 
51. Edelmann, A., Diewok, J., Baena, J. R. \& Lendl, B. High-performance liquid chromatography with diamond ATR-FTIR detection for the determination of carbohydrates, alcohols and organic acids in red wine. Anal. Bioanal. Chem. 376, $92-97$ (2003).

52. Li, R., Dowd, V., Stewart, D. J., Burton, S. J. \& Lowe, C. R. Design, synthesis, and application of a protein A mimetic. Nat. Biotechnol. 16, 190-195 (1998)

53. deJongh, H. H. J., Goormaghtigh, E. \& Ruysschaert, J. M. The different molar absorptivities of the secondary structure types in the amide I region: An attenuated total reflection infrared study on globular proteins. Anal. Biochem. 242, 95-103 (1996).

54. Oberg, K. A., Ruysschaert, J. M. \& Goormaghtigh, E. The optimization of protein secondary structure determination with infrared and circular dichroism spectra. Eur. J. Biochem. 271, 2937-2948, doi: 10.1111/j.1432-1033.2004.04220.x (2004).

55. Barth, A. The infrared absorption of amino acid side chains. Prog. Biophys. Mol. Biol. 74, 141-173 (2000).

56. Kazarian, S. G. \& Chan, K. L. A. ATR-FTIR spectroscopic imaging: recent advances and applications to biological systems. Analyst 138, 1940-1951, doi: 10.1039/c3an36865c (2013).

57. Glassford, S. E., Byrne, B. \& Kazarian, S. G. Recent applications of ATR FTIR spectroscopy and imaging to proteins. Biochimica Et Biophysica Acta-Proteins and Proteomics 1834, 2849-2858, doi: 10.1016/j.bbapap.2013.07.015 (2013).

58. Glassford, S., Chan, K. L. A., Byrne, B. \& Kazarian, S. G. Chemical Imaging of Protein Adsorption and Crystallization on a Wettability Gradient Surface. Langmuir 28, 3174-3179, doi: Doi 10.1021/La204524w (2012).

59. Chan, K. L. A. \& Kazarian, S. G. Attenuated total reflection Fourier-transform infrared (ATR-FTIR) imaging of tissues and live cells. Chem. Soc. Rev. 45, 1850-1864, doi: 10.1039/c5cs00515a (2016).

60. Capito, F., Skudas, R., Kolmar, H. \& Hunzinger, C. At-line mid infrared spectroscopy for monitoring downstream processing unit operations. Process Biochem 50, 997-1005 (2015).

61. Gagnon, P. \& Nian, R. Conformational plasticity of IgG during protein A affinity chromatography. Journal of Chromatography A (2016).

62. Seshadri, S., Khurana, R. \& Fink, A. L. Fourier transform infrared spectroscopy in analysis of protein deposits. Method Enzymol 309, 559 (1999).

63. Capito, F., Skudas, R., Kolmar, H. \& Stanislawski, B. Host cell protein quantification by fourier transform mid infrared spectroscopy (FT-MIR). Biotechnol. Bioeng. 110, 252-259 (2013).

64. Edelmann, A. \& Lendl, B. Toward the optical tongue: Flow-through sensing of tannin-protein interactions based on FTIR spectroscopy. J. Am. Chem. Soc. 124, 14741-14747, doi: 10.1021/ja026309v (2002).

65. Harrick, N. J. Internal reflection spectroscopy. (Harrick Scientific Corp., 1967).

66. Everall, N. J. et al. Preliminary Investigations into Macroscopic Attenuated Total Reflection-Fourier Transform Infrared Imaging of Intact Spherical Domains: Spatial Resolution and Image Distortion. Appl. Spectrosc. 63, 313-320 (2009).

67. Barth, A. The infrared absorption of amino acid side chains. Progress in biophysics and molecular biology 74, 141-173 (2000).

68. Chan, R. \& Chen, V. Characterization of protein fouling on membranes: opportunities and challenges. J. Membr. Sci. 242, 169-188 (2004).

69. Chollangi, S. et al. Development of robust antibody purification by optimizing protein-A chromatography in combination with precipitation methodologies. Biotechnol. Bioeng. 112, 2292-2304 (2015).

70. Chan, K. A., Tay, F. H., Poulter, G. \& Kazarian, S. G. Chemical imaging with variable angles of incidence using a diamond attenuated total reflection accessory. Appl. Spectrosc. 62, 1102-1107 (2008).

\section{Acknowledgements}

The authors wish to thank the BBRSC and the Bioprocessing Research Industry Club (BRIC) for funding this research (BB/K0111030/1). The authors also wish to thank Dr. Cleo Kontoravdi for providing the IgG4c and Pall Corporation for the IgG1 samples.

\section{Author Contributions}

S.G.K. and B.B. conceived the research project; M.B.A., S.G.K. and B.B. designed the research; M.B.A. performed all the experiments; M.B.A., S.G.K. and B.B. analysed the data and M.B.A., S.G.K. and B.B. wrote the manuscript.

\section{Additional Information}

Competing financial interests: The authors declare no competing financial interests.

How to cite this article: Boulet-Audet, M. et al. In-column ATR-FTIR spectroscopy to monitor affinity chromatography purification of monoclonal antibodies. Sci. Rep. 6, 30526; doi: 10.1038/srep30526 (2016).

(c) (i) This work is licensed under a Creative Commons Attribution 4.0 International License. The images or other third party material in this article are included in the article's Creative Commons license, unless indicated otherwise in the credit line; if the material is not included under the Creative Commons license, users will need to obtain permission from the license holder to reproduce the material. To view a copy of this license, visit http://creativecommons.org/licenses/by/4.0/

(C) The Author(s) 2016 